\title{
Pharmacognostic Evaluation of Fruits and Leaves of Annona muricata L
}

\author{
Swapna Birendra', Harisha Ramappa', Satvik Kotha', Raghavendra Rao M², Ramachandra Setty Siddamsetty ${ }^{1, *}$ \\ 'Department of Pharmacology, Government College of Pharmacy, Bengaluru, Karnataka, INDIA. \\ ${ }^{2}$ GM- Clinical Excellence, HCG Bengaluru, Karnataka, INDIA.
}

\begin{abstract}
Objectives: Adulteration in marketed samples has been considered as huge draw-back in fortifying quality herbal products. The study was to investigate and establish leaves, fresh fruit and dry powdered material of pulp, for pharmacognostic standardization parameters as per WHO guideline. Methods: Extracts of Annona muricata (hydroalcoholic and ethyl acetate) were prepared and subjected to preliminary phytochemical screening. Further, the extracts were used to analyse total phenol and flavonoid contents and also estimated antioxidant activities using DPPH and nitric oxide assay. Results: Shape size, color, odour and surface characteristics were noted for fresh fruit. Microscopic images of leaf and powdered fruit exhibited useful diagnostic features. The stomata identified were anamocytic. Vein-islet and vein termination number of leaves of Annona muricata were estimated and reported. Total ash, water soluble and acid insoluble ash was found to be $22.516 \pm 1.854 \%, 7.671 \pm 0.730 \%$ and $11.233 \pm 1.742 \%$ respectively. Loss on drying of dry and fresh fruit was found to be $20.16 \%$ and $78.95 \%$. The water and alcoholic extractive values were $34.4 \%$ and $18.6 \%$. Phytochemical screening revealed the presence of phenols and
\end{abstract}

flavonoids and total flavonoid and phenol content in hydroalcoholic and ethyl acetate extracts of AM and were found to be $240 \mathrm{mg} \mathrm{rut} / \mathrm{g}, 102.0 \mathrm{mg}$ rut $/ \mathrm{g} 12.0408 \mathrm{mg} \mathrm{GAE} / \mathrm{g}$ and, $113.74 \mathrm{mg} \mathrm{GAE} / \mathrm{g}$ respectively. IC ${ }_{50}$ values of $\mathrm{DPPH}$ and nitric oxide assay of hydroalcoholic extracts and ethyl acetate were estimated as $24.557 \mu \mathrm{g} / \mathrm{ml}, 16.847 \mu \mathrm{g} / \mathrm{ml}, 25.883 \mu \mathrm{g} / \mathrm{ml}$ and 23.411 $\mu \mathrm{g} / \mathrm{ml}$ respectively. Conclusion: The findings obtained from the present study helps to authenticate and establish the pharmacopeia standards for AM plant and demonstrated the antioxidant activity of fruit.

Key words: Annona muricata, Ethyl acetate extracts, Hydroalcoholic, DPPH, Stomatal index, Vein-islet.

\section{Correspondence}

Dr. Ramachandra Setty Siddamsetty

Department of Pharmacology, Government College of Pharmacy, Bengaluru-60027, Karnataka, INDIA.

Phone no: +919448633508

Email: rssiddamsetty@rediffmail.com

DOI: 10.5530/ijpi.2020.1.16

\section{INTRODUCTION}

Over the past century, phytochemicals are playing the lead role in the process of drug discovery. In the pharmaceutical landscape, plants with a huge history of use in ethnomedicine and the traditional systems of medicine are rich source of active phytoconstituents that provide health benefits against various ailments and diseases. ${ }^{1}$ Herbal medicines have been used for several thousand years to treat all age groups of patients, because of abundantly available, comparatively cheaper and with minimal side effects. Although the overwhelming influence of herbs and herbal products on modern medicines in the form of lead molecules and their utility in treating more than $70 \%$ of the population, not many herbal preparations are available in a standardized form. Nevertheless, assurance of safety, rigid quality control profiles and efficacy of herbs and herbal products has become an important issue, which needs to be addressed. ${ }^{2}$ Keeping this in view, WHO has set up several guidelines for the standardization of herbal drugs starting from the raw materials to finished products. ${ }^{3,4}$ Annona muricata (AM) is one such plant with extensive traditional use especially in treating cancer, there is marked evidence that anticancer principle of the plant is better extracted in polar solvent like ethyl acetate, alcohol and water. ${ }^{5}$ Hence, hydroalcoholic and ethyl acetate extracts were prepared and the same were subjected for qualitative preliminary phytochemical tests for identification of the category of constituents present. Further, an attempt was made to standardize these extracts for total phenol and flavonoid content. In addition to this, reports are indicating the antioxidant potential of an herb which is indicative of the anticancer potential of it, ${ }^{6}$ therefore, the antioxidant potential was measured by DPPH and nitric oxide scavenging assay. Based

upon the above facts and evidence this plant has been adopted in the present study to investigate and establish the reproducible quality parameter before using the plant material for manufacturing herbal medicines.

\section{MATERIALS AND METHODS}

AM fruits were collected from the Indian Institute of Horticulture, Bangalore and the same were identified, confirmed and authenticated by Dr. V Rama Rao, Regional Ayurveda Research Institute for Metabolic Disorders. The reagents used for the study were of analytical grade.

\section{Macroscopic examinations}

Colour, shape and surface characters were noted by examining the plant material under diffuse daylight. The sample was taken in hand and inhaled to determine the odor and length and width were measured using a graduated ruler in $\mathrm{cm}$.

\section{Microscopic evaluation}

Transverse sections of leaves and powdered fruit of AM were treated with chloral hydrate solution with gentle warming, stained with phloroglucinol and concentrated hydrochloric acid (1:1). They were then mounted with glycerin and studied under a binocular research microscope..$^{7-9}$

The stomatal number and stomatal index: Mid part of the leaf was collected and boiled with chloral hydrate solution. Stomata on both the sides of the leaf were drawn on a black paper using camera lucida. ${ }^{9}$ This was repeated on five separate leaves for reproducibility. The type of sto- 
mata was identified and the stomatal index was calculated by using a formula given below:

$$
I=\frac{S}{E+S} \times 100
$$

Where, $\mathrm{S}=$ Number of stomata

$$
\mathrm{E}=\text { Number of epidermal cells }
$$

\section{Vein islet and veinlet termination}

A piece of leaf was boiled in chloral hydrate solution for about $30 \mathrm{~min}$ and mounted on the slide with glycerin. ${ }^{9}$

\section{Total ash value}

Accurately $2 \mathrm{~g}$ of ground air-dried fruit of AM was weighed in a previously ignited tared crucible of silica. The material was spread in an even layer and ignited at $600^{\circ} \mathrm{C}$ in a muffle furnace until it becomes white, cooled in a desiccator and the weight was noted. Calculated the percentage of ash with reference to air-dried drug.

\section{Water-soluble ash and acid insoluble ash}

Exactly $25 \mathrm{ml}$ of water and hydrochloric acid were added to the crucible containing the total ash and boiled for $5 \mathrm{~min}$. Collected the insoluble matter on an ashless filter paper and washed with hot water and ignited at a temperature not exceeding $450^{\circ} \mathrm{C}$. calculated the percentage of water-soluble and acid insoluble ash with reference to the air-dried drug. ${ }^{9,10}$

\section{Loss on drying}

About $10 \mathrm{~g}$ of the plant material was taken in a china dish, kept in a hot air oven at $105^{\circ} \mathrm{C}$ and the weight of it was measured every hour until a constant weight was attained. ${ }^{11}$ The total moisture content of crude drug was noted.

$$
\text { Loss on drying }(\%)(\mathrm{LOD})=\frac{\mathrm{W}_{2-} \mathrm{W}_{3}}{\mathrm{~W}_{2-} \mathrm{W}_{1}} \times 100
$$

\section{Alcohol and water-soluble extractive value}

About $5 \mathrm{~g}$ of the coarse powder of the crude drug (shade-dried) was weighed and macerated in iodine flask with $100 \mathrm{ml}$ of $70 \% \mathrm{~V} / \mathrm{V}$ alcohol and water for the duration of $24 \mathrm{hr}$ with frequent shaking for $6 \mathrm{hr}$ and finally allowed to stand for $18 \mathrm{hr}$. The solution was filtered rapidly, the filtered solution was evaporated to dryness at $105^{\circ} \mathrm{C}$ in a tarred flat bottomed petri dish. The percentage of the alcohol-soluble extract was determined concerning the shade-dried drug. ${ }^{12}$

\section{Preparation of hydroalcoholic and Ethyl acetate extracts}

Dried and coarsely powdered fruits were subjected to hydroalcoholic and ethyl acetate extract preparation according to the procedure in the manual provided with the instrument (SoxtecTM 2045). The extracts were screened for phytochemical constituents by carrying out the chemical tests like Molish, Tollens, Fehling's, Barford's, Mayer's, Dragendorff's, Wagner's, Hager's, foam test, test for sterol, Salkowski's, LibermannBurchard, ferric chloride, gelatin, chlorogenic, Shinoda, ferric chloride, mineral acid, lead- acetate and sodium hydroxide tests for the respective constituents present. ${ }^{13-15}$

\section{Total flavonoid content}

Flavonoids, the most common group of polyphenolic compounds are found ubiquitously in plants. ${ }^{16}$

- The amount of total Flavonoid content in extracts was determined by aluminum chloride assay by colorimetry.

- The standard stock solution of Rutin $100 \mu \mathrm{g} / \mathrm{ml}$ was prepared
- $\quad 0.5 \mathrm{ml}, 1.0 \mathrm{ml}, 1.5 \mathrm{ml}, 2.0 \mathrm{ml}$ and $2.5 \mathrm{ml}$ of above stock solution was pipetted into $10 \mathrm{ml}$ volumetric flasks

- Hydroalcoholic and ethyl acetate extracts of AM were dissolved separately to get $1 \mathrm{mg} / \mathrm{ml}$.

- $\quad 0.5 \mathrm{ml}$ of each test extract solution was pipetted into $10 \mathrm{ml}$ volumetric flasks (taken in triplicate).

- $\quad 0.3 \mathrm{ml}$ of sodium nitrite $\left(5 \% \mathrm{NaNO}_{2} \mathrm{w} / \mathrm{v}\right)$ was added to volumetric flasks of test extract and standard and allowed to stand for $6 \mathrm{~min}$.

- $\quad 0.3 \mathrm{ml}$ of aluminum trichloride $\left(10 \% \mathrm{AlC}_{13}\right)$ was added and incubated for $6 \mathrm{~min}$ at room temperature, followed by $4 \mathrm{ml}$ of sodium hydroxide $(\mathrm{NaOH}, 4 \% \mathrm{w} / \mathrm{v})$ and the volume was made up to $10 \mathrm{ml}$ with distilled water for standard and test extract.

- The samples were incubated at room temperature in dark for 15 min.

- After 15 min, the mixture turns pink whose absorbance was measure at $510 \mathrm{~nm}$ using a UV spectrophotometer (Shimadzu 1800).

- Methanol was used as blank.

- The calibration curve was constructed for standard rutin.

- Based on the test extract absorbance, the concentration of the flavonoids in the extracts was expressed as $\mathrm{mg}$ rutin/g dry weight (DW) (mg rutin/g DW)

- The concentration of total flavonoid compounds in the extract was determined by using the formula: ${ }^{17}$

\section{$\mathrm{T}=\mathrm{CV} / \mathrm{M}$}

Where, $\mathrm{T}=$ Total flavonoid content in $\mathrm{mg}$ rutin/g dry weight (mg rutin/g DW) of plant extract

$\mathrm{C}=$ Concentration of rutin obtained from the calibration curve

$\mathrm{V}=$ Volume of the extract in $\mathrm{ml}$

$\mathrm{M}=$ weight of the plant extract taken

\section{Total phenol content}

The total phenolic content was estimated by Folin Ciocalteu's method using gallic acid as standard. ${ }^{18}$

- Folin cciocalteu reagent was prepared by diluting 1 volume of ready to use Folin Ciocalteu reagent with 2 volumes of distilled water.

- The standard stock solution of gallic acid $100 \mu \mathrm{g} / \mathrm{ml}$ was prepared.

- $\quad 0.5 \mathrm{ml}, 1.0 \mathrm{ml}, 1.5 \mathrm{ml}, 2.0 \mathrm{ml}$ and $2.5 \mathrm{ml}$ of the above stock solution were pipetted into $25 \mathrm{ml}$ o volumetric flasks.

- Hydroalcoholic and ethyl acetate extract of AM were dissolved separately to get $1 \mathrm{mg} / \mathrm{ml}$.

- $\quad 0.5 \mathrm{ml}$ of each extract solution was pipette into $25 \mathrm{ml}$ of volumetric flasks (taken in triplicate).

- Blank was prepared with $1 \mathrm{ml}$ of solvent methanol (without test extract or standard).

- $\quad 1.5 \mathrm{ml}$ of folin ciocalteu reagent was added to volumetric flasks of test extract, standard and blank.

- After $5 \mathrm{~min}, 4 \mathrm{ml}$ of $20 \%$ sodium bicarbonate solution was added to volumetric flasks of test extract, standard and blank made up to 25 $\mathrm{ml}$ with distilled water.

- The samples were incubated for $45 \mathrm{~min}$ at room temperature and absorbance was measured at $765 \mathrm{~nm}$ using a UV spectrophotometer

- Calibration was constructed for standard gallic acid.

- Based on the absorbance of test extract, the concentration of phenolics was calculated $(\mathrm{mg} / \mathrm{ml})$ from the calibration curve; content of phenolics in the extracts was expressed in terms of gallic acid equivalent (GAE) (mg of GA/g of extract). 
- The concentration of total phenolic compounds in the extract was determined by using the formula:

$\mathrm{T}=\mathrm{CV} / \mathrm{M}$

Where, $\mathrm{T}=$ Total phenolic content in $\mathrm{mg} / \mathrm{g}$ in terms of GAE

$\mathrm{C}=$ Concentration of gallic acid obtained from the calibration curve

$\mathrm{V}=$ Volume of the extract in $\mathrm{ml}$

$\mathrm{M}=$ weight of the plant extract taken

\section{Antioxidant activity by DPPH radical scavenging method}

The DPPH assay is based on the reduction of DPPH, a stable free radical. ${ }^{19,20}$

- Accurately weighed $3.94 \mathrm{mg}$ of the DPPH was dissolved in $100 \mathrm{~mL}$ of methanol to get $0.1 \mathrm{mM} \mathrm{DPPH}$.

- Different concentrations of the standard (ascorbic acid) and plant extracts like $5,10,15,20,25$ and $30 \mu \mathrm{g} / \mathrm{mL}$ were prepared in triplicate by diluting with methanol.

- Exactly $1 \mathrm{~mL}$ of each of standard/test samples were mixed with 3 $\mathrm{ml}$ of DPPH and kept in dark place for 30min to protect from light.

- DPPH solution alone was taken as control and methanol was used as blank.

- The absorbance was measured at $517 \mathrm{~nm}$ using a UV-Visible spectrophotometer.

The \% inhibition was calculated by using a formula and compared with the values of standard ascorbic acid.

$\%$ inhibition of DPPH $=\left(\mathrm{A}_{0}-\mathrm{A}_{1}\right) \quad \mathrm{X} 100$

Where, $A_{0}$ is the absorbance of control

$\mathrm{A}_{1}$ is the absorbance of extract/standard.

The $\mathrm{IC}_{50}$ value was determined and compared with the standard ascorbic acid.

\section{Nitric oxide radical scavenging activity}

- Nitric oxide scavenging assay was performed using the Griess reagent method. ${ }^{21}$

- Different concentrations of the standard (ascorbic acid) and test extracts $10,20,30,40$ and $50 \mu \mathrm{g} / \mathrm{ml}$ were prepared in triplicate and made up the volume to $1 \mathrm{ml}$ with methanol.

- Exactly $0.3 \mathrm{ml}$ of $10 \mathrm{mM}$ sodium nitroprusside was added to $1 \mathrm{ml}$ of each of standard/plant extract.

- The test tubes were incubated at $25^{\circ} \mathrm{C}$ for $150 \mathrm{~min}$ and $0.5 \mathrm{ml}$ of Griess reagent was added.

- Control was prepared using the same procedure except for extract and ascorbic acid and methanol was used as blank.

- The absorbance was measured at $546 \mathrm{~nm}$ using UV- visible spectrophotometer

The $\%$ inhibition was calculated using a formula given below.

$\%$ inhibition of NO scavenging activity $=\left(\mathrm{A}_{0}-\mathrm{A}_{1}\right) \mathrm{X} 100$

Where $\mathrm{A}_{0}$ is the absorbance of control

$A_{1}$ is the absorbance of extract/standard.

The $\mathrm{IC}_{50}$ value was determined and compared with the standard ascorbic acid.

\section{RESULTS}

\section{Macroscopic examinations}

Fruits are large, fleshy and ovoid/heart-shaped, weighing about 2.5 to 4 $\mathrm{kg}$, measures 17 to $15.5 \mathrm{~cm}$ in length and 28 to $26.5 \mathrm{~cm}$ width. The fruits are dark green in unripe condition, slightly lighter green when ripe. Skin is soft and fairly outlined in rhomboidal areas, numerous fused carpels and recurved spine in the center of each rhomboid. It contains 127 to 170 seeds, black in color, the coat is very hard and its size varies from 1 to 2 $\mathrm{cm}$ in length, 0.33 to $0.59 \mathrm{~cm}$ in width. The pulp is white/ creamy white and juicy, pleasantly subacid, with a slight mango-like flavor. The rind has many short, fleshy, pointed carpel protuberances and rough texture with numerous spines on the surface of the fruit. The picture of AM is shown in Figure 1a.

\section{Microscopic characteristics}

The microscopic examinations of leaves of AM revealed the presence of vascular bundles covered with a thick cuticle, phloem fibers, collenchyma, pitted parenchyma, oil globule, spongy, palisade and mesophyll tissue, unicellular trichomes and stomata (Figure 1b-1i). The thickness of each tissue of TS of leaf is measured and compiled in Table 1.

\section{Table 1: Measurements of tissues.}

\begin{tabular}{|c|c|}
\hline Parenchyma & 2883.20X2854.10 $\mu \mathrm{m}$ \\
\hline Phloem Fiber & $16800.50 X 17732.76 \mu \mathrm{m}$ \\
\hline Collenchyma & 1433.40X $2053.60 \mu \mathrm{m}$ \\
\hline Xylem & 2336.60X2053.60 $\mu \mathrm{m}$ \\
\hline Phloem & $12137.64 X 842.50 \mu \mathrm{m}$ \\
\hline Epidermal cells & 26803.26X17032.19 $\mu \mathrm{m}$ \\
\hline Stomata & $\mu \mathrm{m}$ \\
\hline
\end{tabular}
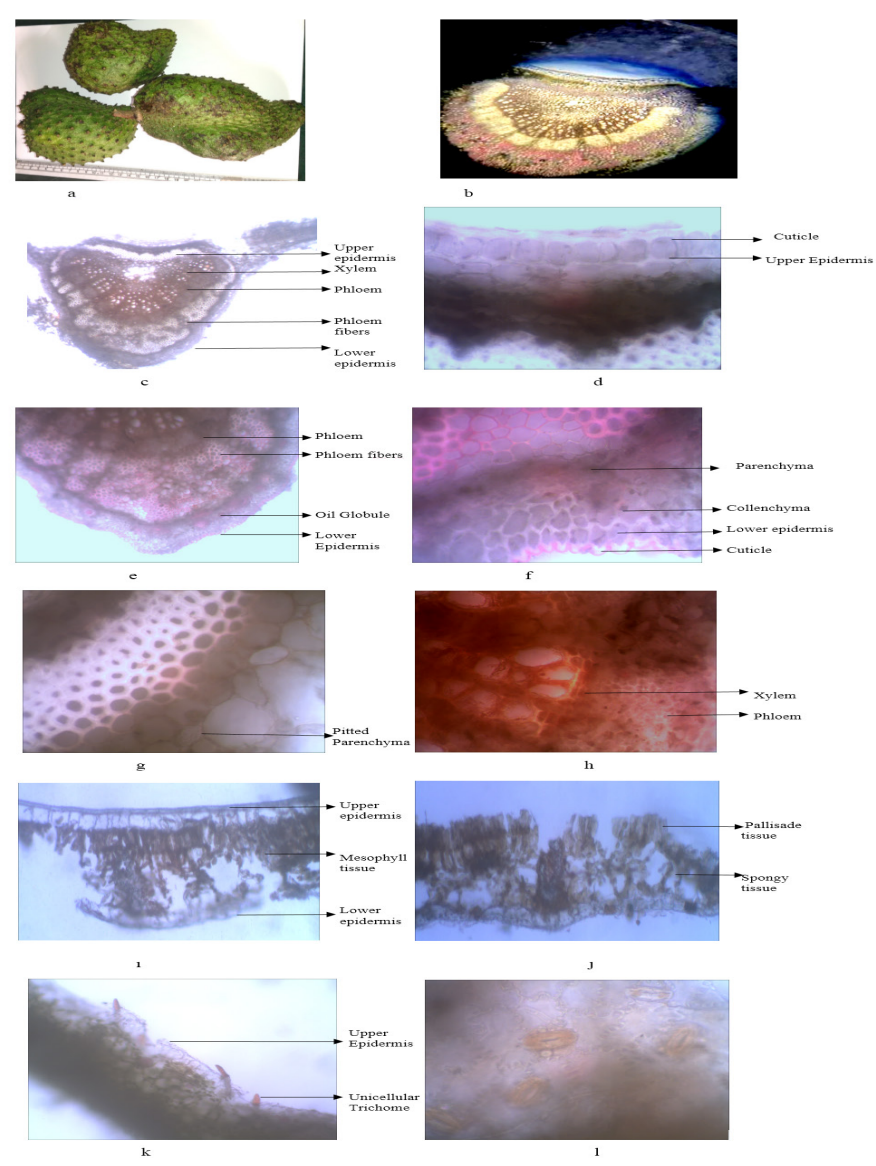

Figure 1: Morphology of the fruit, $1 \mathrm{~b}$ to $\mathrm{l}$ :Transverse section of the leaf. 


\section{Stomatal number and index and Vein islet number and vein termination number}

The microscopic study revealed that the leaf is amphistomatous having anamocytic type of stomata. The stomata density is measured as the stomatal index. The stomatal index on the upper and lower surface are $9.462 \pm 1.474 \%$ and $15.38 \pm 2.234 \%$ with reference to epidermal cells per sq. $\mathrm{mm}$ respectively. Similarly, vein termination and vein islet numbers are $21 \pm 2.002$ sq. $\mathrm{mm}$ and $31.333 \pm 3.756$ per sq. $\mathrm{mm}$ (Table 2 ) and the picture of a randomly selected leaf is Figure $2 \mathrm{a}, \mathrm{b}$ and $\mathrm{c}$.

\section{Determination of ash value}

Total ash value, water-soluble ash value and acid-insoluble ash values are $22.516 \pm 1.854,7.671 \pm 0.730$ and $11.233 \pm 1.742$ respectively.

\section{Loss on drying and extractive values}

The moisture content of dry and fresh pulp is $20.16 \%$ and $78.95 \%$ respectively. The water and alcoholic extractive values of the dry pulp are found to be $34.4 \%$ and $18.6 \%$ respectively.

\section{Extraction of AM fruit}

The color of hydroalcoholic and ethyl acetate extract of AM was found to be brown in color and semisolid inconsistency. The yield of hydroalcoholic extract and ethyl acetate extract was found to be $7.18 \%$ and $0.692 \%$ respectively.

All the standardization parameter results are tabulated in Table 2.

Table 2: Standardization parameter of Annona muricata.

\begin{tabular}{ccc}
\hline SI no & Standardization Parameters & Mean \pm SEM \\
\hline 1 & Stomatal index (\%) & Lower epidermis: $15.38 \pm 2.234 n=5$ \\
& Upper epidermis: $9.462 \pm 1.474 n=5$
\end{tabular}

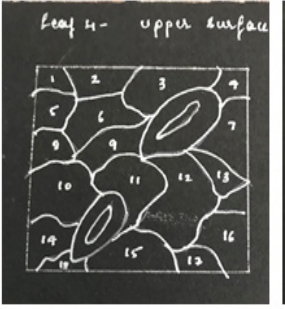

a

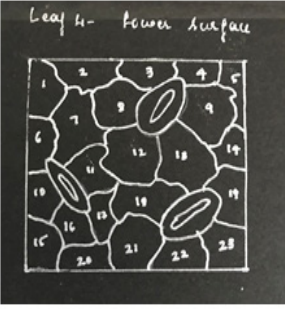

b

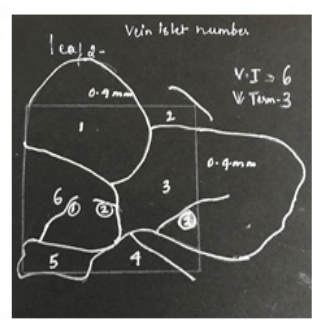

Figure $\mathbf{2} \mathbf{a}$ and $\mathbf{b}$ : Stomata and epidermal cells of an upper surface and lower surface c: vein-islet and vein termination.

\section{Powder microscopy characteristics}

The powder microscopic study showed the presence of polygonal lignified stone cells with a pitted lumen in groups. Thin-walled parenchymatous cells, rounded simple starch grains, oil globules groups of spiral xylem vessels and small rosette crystals of calcium oxalate. The powder microscopic observations are depicted in Figure 3a-g.

\section{Phytochemical Investigation}

The extracts of hydroalcoholic and ethyl acetate were further subjected to phytochemical screening and results are tabulated in Table 3.

\section{Total flavonoid content and total phenolic content}

The total flavonoid content in hydroalcoholic and ethyl acetate extracts of AM and was found to be $240 \mathrm{mg}$ rut $/ \mathrm{g}$ and $102.0 \mathrm{mg}$ rut/g respectively and total phenol content was found to be $12.0408 \mathrm{mg} \mathrm{GAE} / \mathrm{g}$ and 113.74 mg GAE/g. Results of flavonoid and phenol content are tabulated in Table 4 and standard calibration curve graphically depicted below (Figure $4 \mathrm{a}$ and $4 \mathrm{~b}$ ).

Table 3: Results of phytochemical investigation of AM fruit extracts.

\begin{tabular}{|c|c|c|c|c|}
\hline \multirow{2}{*}{$\begin{array}{l}\text { SI } \\
\text { No }\end{array}$} & \multirow{2}{*}{$\begin{array}{l}\text { Chemical } \\
\text { Constituents }\end{array}$} & \multirow[t]{2}{*}{ Test } & \multicolumn{2}{|c|}{ Results } \\
\hline & & & $\begin{array}{c}\text { Hydroalcoholic } \\
\text { Acetate }\end{array}$ & $\begin{array}{c}\text { Ethyl } \\
\text { acetate }\end{array}$ \\
\hline \multirow[t]{4}{*}{1} & Carbohydrates & Molish test & + & + \\
\hline & & Tollens test & - & + \\
\hline & & Fehlings $\mathrm{A}$ and $\mathrm{B}$ & - & + \\
\hline & & Barford's & + & - \\
\hline \multirow[t]{4}{*}{2} & Alkaloids & Mayer's test & - & - \\
\hline & & $\begin{array}{l}\text { Dragendorff's } \\
\text { test }\end{array}$ & + & + \\
\hline & & Wager's test & + & + \\
\hline & & Hager's test & - & + \\
\hline 3 & Saponins Test & Foam test & + & + \\
\hline \multirow[t]{2}{*}{4} & Steroidal test & Salkowski's test & + & + \\
\hline & & $\begin{array}{c}\text { Libermann } \\
\text { Burchard test }\end{array}$ & + & - \\
\hline \multirow[t]{3}{*}{5} & Triterpenoidal & Salkwoski's test & & - \\
\hline & test & $\begin{array}{l}\text { Libermann - } \\
\text { Burchard test }\end{array}$ & + & - \\
\hline & & Iscugajiu test & + & + \\
\hline \multirow[t]{3}{*}{6} & Phenol test & $\begin{array}{c}\text { Ferric chloride } \\
\text { test }\end{array}$ & + & + \\
\hline & & Gelatin test & - & - \\
\hline & & Chlorogenic test & - & - \\
\hline \multirow[t]{5}{*}{7} & Flavonoid test & Shinoda test & + & - \\
\hline & & $\begin{array}{c}\text { Ferric chloride } \\
\text { test }\end{array}$ & + & + \\
\hline & & Mineral test & + & + \\
\hline & & Lead acetate test & + & + \\
\hline & & $\begin{array}{l}\text { Sodium } \\
\text { hydroxide test }\end{array}$ & + & + \\
\hline
\end{tabular}




\section{Determination of the antioxidant activity of by DPPH} and nitric oxide radical scavenging method

The anti-oxidant activity of AM fruit is assessed by the DPPH scavenging assay. Ascorbic acid was selected as standard, showed an $\mathrm{IC}_{50}$ value of $15.893 \mu \mathrm{g} / \mathrm{ml}$ IC $_{50}$ values of ethyl acetate and hydroalcoholic extracts were estimated as $16.847 \mu \mathrm{g} / \mathrm{ml}$ and $24.557 \mu \mathrm{g} / \mathrm{ml}$ respectively. Similarly, the antioxidant activity of AM is also assessed by nitric oxide scavenging assay. The $\mathrm{IC}_{50}$ value of ascorbic acid was determined as $29.759 \mu \mathrm{g} /$ $\mathrm{ml}$. IC $\mathrm{I}_{50}$ values of $23.411 \mu \mathrm{g} / \mathrm{ml}$ and $25.883 \mu \mathrm{g} / \mathrm{ml}$ corresponds to ethyl acetate and hydroalcoholic extracts of fruits of AM. The results are presented in Table 5 and the graph in Figure $5 a$ and $5 b$.

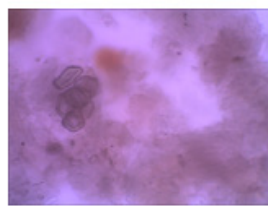

a

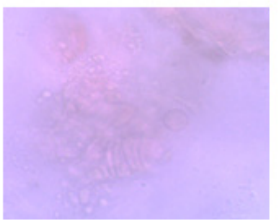

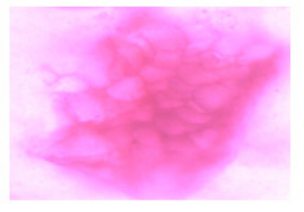

b
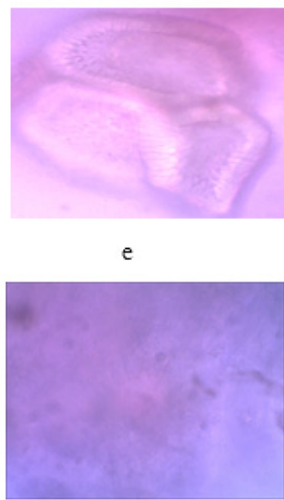
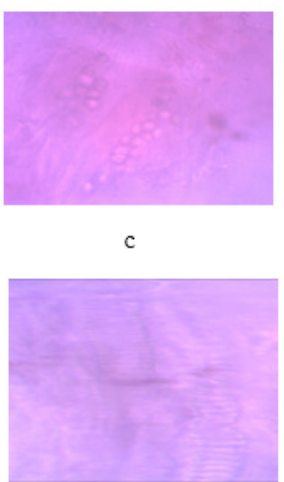

f
Figure 3: a) Stone cells in groups b) Thin-walled parenchymatous cells c) Round simple starch grains d) Oil globules e)Polygonal highly lignified stone cells with pitted lumen f) Groups of enlarged spiral xylem vessels g) Small rosette crystals of calcium oxalate.

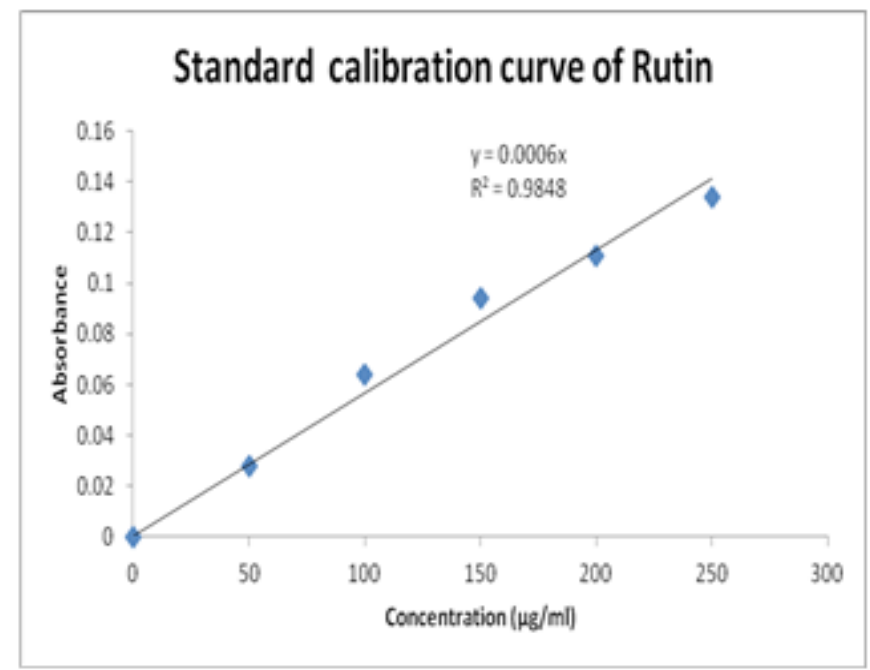

\section{DISCUSSION}

Results of morphological and organoleptic characteristics of AM fruits were found to conform with the literature. ${ }^{8}$ The microscopic examinations of leaves of AM revealed the presence of vascular bundles, the upper epidermal region covered by thick cuticle, phloem fibers, collenchyma, pitted parenchyma, oil globule, spongy, palisade, mesophyll tissue, unicellular trichomes and stomata (Figure 1a-1). Further Powder microscopy of fruits showed the presence of stone cells in groups, polygonal highly lignified stone cells with the pitted lumen, thin-walled parenchymatous cells, rounded simple starch grains, oil globules, groups of spiral xylem vessels, small rosette crystals of calcium oxalate (Figure 3 ). The size of all the above-mentioned cells was measured and tabulated in Table 1. These diagnostic features may be used to authenticate and to detect the adulteration.

The type of stomata identified was anamocytic. The stomatal index of the lower and upper surface of AM was determined as $15.38 \pm 2.234 \%$ and $9.462 \pm 1.474$ respectively whereas, vein-islet and vein termination number of leaves of AM were estimated as $31.333 \pm 3.756 \mathrm{~mm}^{2}$ and $21 \pm 2.002 \mathrm{~mm}^{2}$ (Figure 2a, 2b and 2c) and (Table 2). Development of type of stomata and stomatal index depends on the environment in which the plant grows i.e. $\mathrm{CO}_{2}$ rich environment and the intensity of light alters the stomatal index..$^{22}$ Hence the stomatal index values obtained are specific to the plants grown in that environment. Therefore before using the stomatal index as identification or standardization parameter; the environment in which the plant is grown has to be considered. However type of stomata will not change upon a change in environmental conditions.

As a part of the proximate analysis, total ash, water-soluble and acid insoluble ash values were determined (Table 2) and gives an idea about the existence of carbonates, phosphates, silicates, silica and other inorganic impurities along with the drug. Alteration in ash values are useful for the identification, authentication, standardization of herbal material and also possibly indicate the adulteration. Loss on drying and water and alcohol extractive value (Table 2 ) indicates the presence of moisture content and useful for establishing the storage stability of plant material and the extractive value indicates the quantum of water-soluble and alcohol-soluble substances and can be used for standardizing the plant material. Hydroalcoholic and ethyl acetate extracts were prepared and subjected to a qualitative preliminary phytochemical test for identification of the

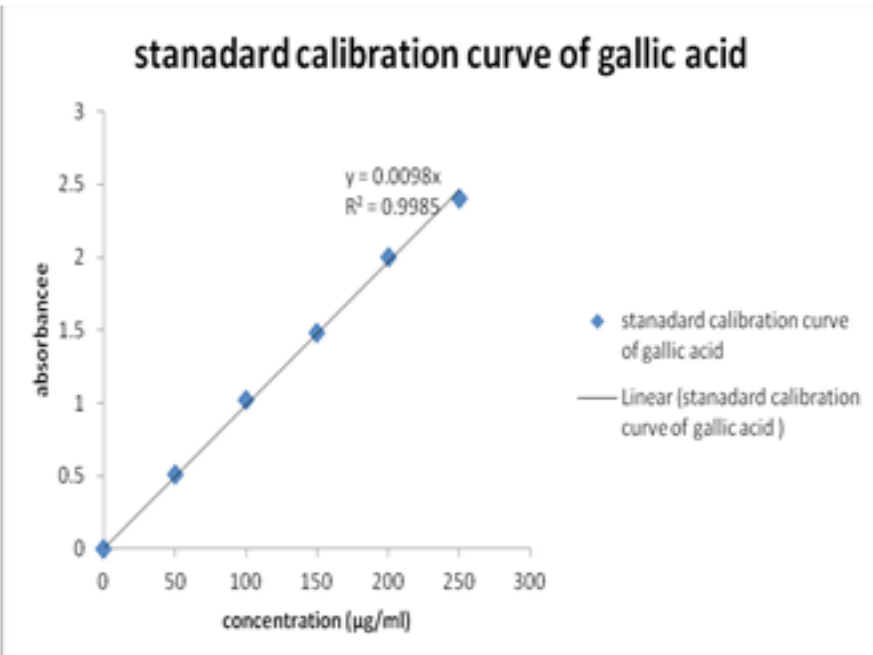

b

Figure 4: (a) and (b) Standard calibration curve of Rutin. 


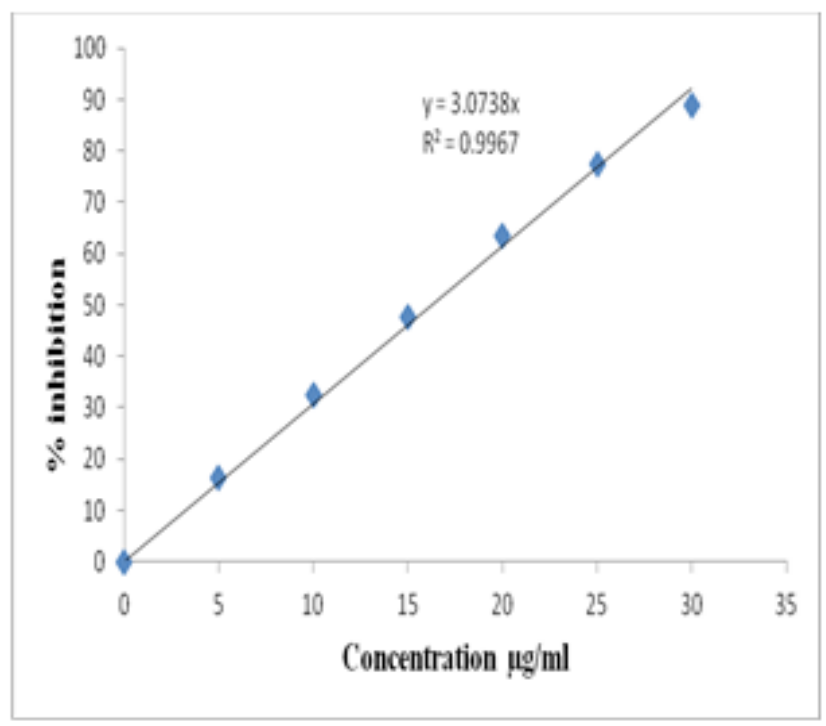

a

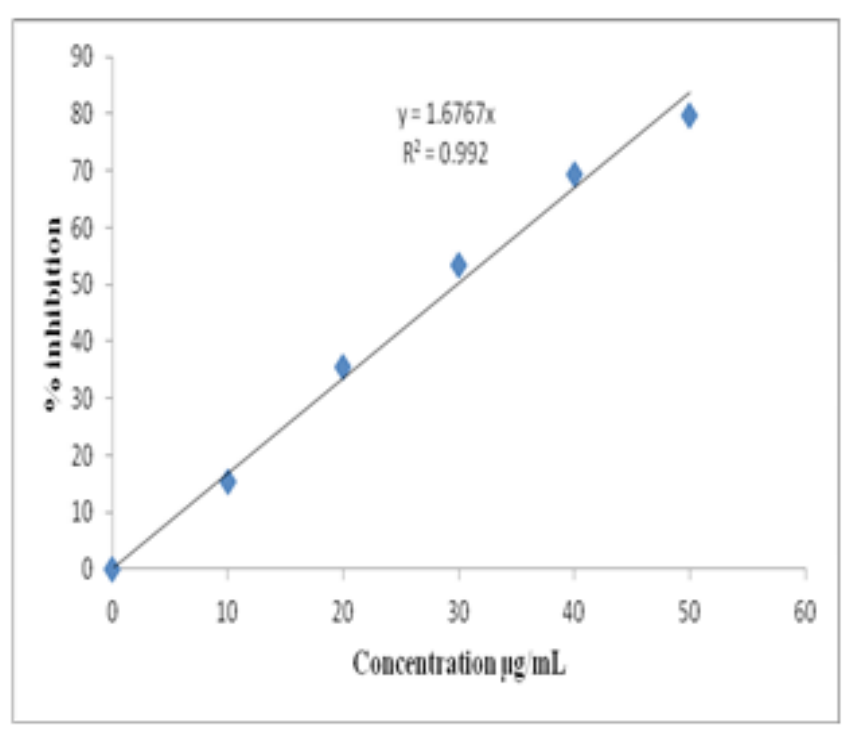

b

Figure 5: (a): Standard calibration curve of ascorbic acid by DPPH radical scavenging method (b): Standard calibration curve of ascorbic acid by nitric oxide radical scavenging method.

Table 4: Total Flavonoid content of hydroalcoholic and ethyl acetate extract of AM.

\begin{tabular}{|c|c|c|c|c|c|}
\hline Name of the assay & $\begin{array}{l}\text { concentration } \\
(\mu \mathrm{g} / \mathrm{ml}) \text { Rutin }\end{array}$ & Absorbance & Name of the assay & $\begin{array}{l}\text { concentration }(\mu \mathrm{g} / \\
\mathrm{ml}) \text { gallic acid }\end{array}$ & Absorbance \\
\hline \multirow[t]{6}{*}{ Flavonoid content } & 0 & 0 & Phenol content & 0 & 0 \\
\hline & 50 & 0.028 & & 50 & 0.513 \\
\hline & 100 & 0.064 & & 100 & 1.020 \\
\hline & 150 & 0.096 & & 150 & 1.480 \\
\hline & 200 & 0.111 & & 200 & 2.000 \\
\hline & 250 & 0.134 & & 250 & 2.400 \\
\hline $\begin{array}{c}\text { Hydroalcoholic } \\
\text { extract }\end{array}$ & $\begin{array}{l}1 \mathrm{mg} / \mathrm{ml}(0.5 \\
\mathrm{ml})\end{array}$ & 0.072 & $\begin{array}{c}\text { Hydroalcoholic } \\
\text { extract }\end{array}$ & $1 \mathrm{mg} / \mathrm{ml}(0.5 \mathrm{ml})$ & 0.059 \\
\hline Ethylacetate extract & $\begin{array}{c}1 \mathrm{mg} / \mathrm{ml}(0.5 \\
\mathrm{ml})\end{array}$ & 0.0306 & Ethylacetate extract & $1 \mathrm{mg} / \mathrm{ml}(0.5 \mathrm{ml})$ & 0.557 \\
\hline
\end{tabular}

category of constituents present. The results revealed that hydroalcoholic and ethyl acetate extracts of AM contain carbohydrates alkaloids, phenols, flavonoids, steroids, triterpenoids, saponins (Table 3).

An attempt was made to standardize these extracts for total flavonoid and total phenol content by using aluminum chloride assay by colorimetry and folin ciocalteu's method. Total flavonoid content of hydroalcoholic and ethyl acetate of AM was found to be $240 \mathrm{mg}$ rut/ $\mathrm{g}$ and 102.0 $\mathrm{mg}$ rut/g respectively.Total phenol content of hydroalcoholic and ethyl acetate of AM was found to be $12.040 \mathrm{mg} \mathrm{GA} / \mathrm{g}$ and $113.74 \mathrm{mg}$ of GAE/g respectively. These findings are useful in co-relating anticancer potency of study plants with that of their phenol and flavonoid content. This will be useful not only for fixing the dose but also useful for enriching the plant material so that efficacy may be increased.

The anti-oxidant activity of AM fruit is assessed by the DPPH and nitric oxide scavenging assay it is evident from the results (Table 5) that ethylacetate extract of the plant showed more antioxidant activity in compari-
Table 5: Antioxidant activity of standard ascorbic, hydroalcoholic and ethyl acetate extracts by DPPH and nitric oxide radical scavenging assay.

\begin{tabular}{cccc}
\hline SI no & Assay & Treatment & $\begin{array}{c}\text { Average IC } \\
(\mu \mathrm{g} / \mathrm{ml})\end{array}$ \\
\hline 01 & $\begin{array}{c}\text { DPPH } \\
\text { radical } \\
\text { scavenging } \\
\text { method }\end{array}$ & Standard ascorbic acid & 15.893 \\
02 & $\begin{array}{c}\text { Nitric oxide } \\
\text { scavenging } \\
\text { method }\end{array}$ & Ethylacetate extract & 24.557 \\
& & Hydroalcoholic extract & 16.847 \\
& & Ethylacetate extract & 29.859 \\
\hline
\end{tabular}


son with hydroalcoholic extracts, which may be ascribed to the high content of phenols. Further, reports given by Vijayameena and Subhashini et al. ${ }^{23}$ indicate the presence of Vitamin C, Vitamin E, SOD and catalase in leaves and seeds of AM, which could be supportive evidence for the predominant antioxidant activity exhibited by said plant extracts.

There is a report that nitric oxide involvement in tumorigenesis is multifactorial. Nitric oxide can participate in the complicated process of carcinogenesis by mediating DNA damage in early phases of tumorigenesis, as well as support tumor progression through the induction of angiogenesis and suppression of the immune response. The study extracts scavenged off nitric oxide radicals efficiently, indicating that these extracts possess anticancer property. ${ }^{24}$ The study results are indicating that extracts of study plants are found to be more potent or equipotent with that of the standard. The whole investigation could serve as a basis for proper identification of the plant material and helps the investigator to distinguish the plant from other members of the same genera. Even these parameters can be used as standardization parameters and also for the identification of adulterants.

\section{CONCLUSION}

The conclusion drawn from the present study is that the various parameters like microscopic, macroscopic, proximate values, etc. may be used for the identification of the study herb or the herbal products and also for the detection of adulteration. Further antioxidant activities demonstrated by the study plants indicating that these may possess anticancer activity. It is also designed to take up the study further to evaluate the anticancer potential of these plants by adopting in vitro and in vivo models of cancers.

\section{ACKNOWLEDGEMENT}

The authors thank Dr. V. Rama Rao and Dr. T.R Shantha, consultant (Pharmacognosy), Regional Ayurveda Research Institute For Metabolic Disorder, (Central Council For Research in Ayurvedic Sciences, Ministry of Ayush, Govt. of India) for identifying, authenticate and also helping in carrying out methodology technically.

\section{CONFLICT OF INTEREST}

The authors declare no conflict of interest.

\section{AUTHORS' CONTRIBUTIONS}

Swapna B and Harisha R (Ph.D. students) and Satvik Kotha contributed to collecting plant samples and identification, running the laboratory work, analysis of the data and drafted the paper. Dr. Ramachandra Setty $\mathrm{S}$ and Raghavendra Rao M contributed to conceptualization, design, supervision, critical analysis of data and preparing the manuscript. All the authors have read the final manuscript and approved the submission.

\section{ABBREVIATIONS}

AM: Annona Muricata; DPPH: 2,2-diphenyl-1-picrylhydrazyl; RUT: Rutin; GAE: Gallic acid Equivalent; WHO: World Health Organization.

\section{REFERENCES}

1. Moghadamatousi SZ, Fadaenasab M, Nikzad S, Mohan G, Ali HM, Kadir HA. Annona muricata (Annonaceae): A Review of its Traditional uses, Isolated Acetogenins and Biological Activities. Int J Mol Sci. 2015;16(17):15625-58.

2. Kulkarni KM, Patil LS, Khanvilkar VV, Kadam VJ. Fingerprinting Techniques in Herbal Standardization. Indo American J Pharm Res. 2014;4(02):1049-61.

3. Swarnakar A. Literary approach to Annona muricata and its role in cancer: A review. Int Res Pharmacol Pharmacother. 2014;3(4):320-7.

4. Deb J, Dash GK. Pharmacognostical studies on stem bark of Acacia feruginea DC. Scholar Res Lib. 2014;6(3):61-6.

5. Avinash DK, Waman SN. Phytochemical constituents of leaves of Paniculatus wild: Endangered medicinal plant. Int J Pharmacog Phytochem Res. 2014;6(4):792-4

6. Munro B, Vuong OV, Chalmers AC, Goldsmith CD, Bowyer MC, Scaelett CJ. Phytochemical, antioxidant and anticancer properties of Euphorbia tirucalli methanol and aqueous extracts. Antioxidants. 2015;4(4):647-61.

7. Kokate CK, Purohit AP, Gokhale SB. Pharmacognosy. Pune: Nirali prakashan. 2006

8. Wallis TE. Pharmacognosy. London: TA Churchill. 1985.

9. Khandelwal KR. Practical pharmacognosy, Techniques and experiments. Pune: Nirali Prakashan. 2007.

10. Mukherjee PK. Quality Control of Herbal Drugs, An approach to evaluation of Botanicals. New Delhi: Business Horizon Pharmaceutical Publishers. 2012.

11. The Indian pharmacopeia Ghaziabad. National Institute of Science Communication and Information Resources. New Delhi: Council of Scientific and Industrial Research Publications. 2017;287.

12. Kokate CK. Practical pharmacognosy. Delhi: Vallabh Vrakashan. 2008;149-56.

13. Chauhan A, Mittu B. Phyto-chemical Screening and Anti Listerial activity of Annona muricata (L) leaf extract. J Chromatogr Sep Tech. 2015;6(3):1-4.

14. Banu KS, Catherine L. General techniques involved in phytochemical analysis. International. J Advan Res Chem Sci. 2015;2(4):25-32.

15. Krisgnaveni G, Sailaja O, Mounika K. Identification and estimation of phytochemicals from the plant Pedicularis bicornuta leaf extract by UV-Spectrophotometry. Res Desk. 2014;3(1):410-8.

16. Bhaigyabati T, Devi PG, Bag GC. Total flavonoid content and antioxidant activity of aqueous rhizome extract of three hedychium species of Manipur valley. Res J Pharm Biol Chem Sci. 2014;5(5):970.

17. Malla MY, Sharma M, Saxena RC, Mir MI, Mir AH, Bhat SH. Phytochemical screening and spectroscopic determination of total phenolic and flavonoid contents of Eclipta Alba Linn. J Nat Prod Plant Resour. 2013;3(2):86-91.

18. Tupe RS, Kemse NG, Khaire, AA. Evaluation of antioxidant potentials and total phenolic contents of selected Indian herbs powder extracts. Int Food Res J. 2013;20(3):1053-63

19. Ojezele OJ, Ojezale MO, Adeosun AM. Comparative Phytochemistry and Anioxidant Activities of Water and Ethanol Extract of Annona muricata linn leaf, Seed and Fruit. Adv Biol Res. 2016;10(4):230-5.

20. Blois MS. Antioxidant determination by the use of stable free radicals. Nature. 1958;181:1199-200.

21. Parul $R$, Kundu SK, Saha P. In vitro Nitric oxide Scavenging Activity Of methanol Extracts of Three Bangladeshi Medicinal plants. The Pharma Innovation J. 2013;1(12):83-8.

22. Casson S, Gray JE. Influence of environmental factors on stomatal development. New Phytologist. 2008;178(1):9-23.

23. Vijayameena C, Subhasini G, Loganayani M, Ramesh B. Phytochemical screening and assessment of antibacterial activity for the bioactive compounds in $A n-$ nona muricata. Int J Curr Microbiol App Sci. 2013;2(1):1-8.

24. Moochhala S, Rajnakova A. Role of nitric oxide in cancer biology. Free Rad Res. 1999;31(6):371-9 